\title{
РАЗГОВОР ПРИ ЗНАКОМСТВЕ: КОНВЕРСАЦИОННЫЙ АНАЛИЗ БЫСТРЫХ СВИДАНИЙ
}

\author{
А.М. УЛАНОВСКИЙ ${ }^{\text {a }, ~ Л . А . ~ Е Р О Х И Н А ~}$ \\ ${ }^{a}$ Национальньй исследовательский университет «Высшая школа экономики», 101000, Россия, \\ Москва, ул. Мясницкая, д. 20 \\ ${ }^{b}$ Институт русского языка РАН, 119019, Москва, ул. Волхонка, 18/2
}

\begin{abstract}
Резюме
Статья посвящена анализу разговоров при знакомстве на материале записей быстрых свиданий. Рассматривается проблематика исследований романтического дискурса. Описан формат быстрых свиданий (speed dating), который не только является самобытным культурным и социально-психологическим феноменом и специальным жанром разговора, но также трактуется сегодня как многообещающая методология изучения коммуникации, межличностных отношений и аттракции. Представлен обзор исследований на основе этой методологии. Отдельное место отведено рассмотрению метода конверсационного анализа, созданного Х. Саксом с коллегами в конце 1950-х гг. для решения прикладных задач экспертизы телефонных звонков, относящегося к группе качественных методов исследования в социальных науках и ориентированного на детальный анализ коротких эпизодов разговорного обмена двух и более собеседников. Предлагается модель анализа повседневных разговоров, включающая элементы сцены-контекста, общего дизайна разговора, способов смены очереди говорящих, повторяющихся паттернов, коммуникативных затруднений и институциональной специфики разговоров. Представлены результаты эмпирического исследования разговоров молодых людей и девушек в ходе знакомства на вечеринках быстрых свиданий $(\mathrm{N}=48)$. Выделены и описаны феномены разговора в данной ситуации: типичные и нетипичные способы начала, увеличение размера очереди по ходу общения, паттерн «вопрос - ответ - комментарий», поиск взаимной схожести как стратегия говорящих, перехват инициативы, прямая передача очереди, перевод темы как уход от конфронтации, шаблоны фраз, смягчающие недопонимание действия, запинки и их влияние на ход разговора, переспрос, конвейерность взаимодействия, перенос содержания и отложенное реагирование, «телеграфный стиль», отсутствие закрытия разговора, гендерная асимметрия взаимодействия.
\end{abstract}

Ключевые слова: разговор, взаимодействие, конверсационный анализ, знакомство, быстрые свидания.

Статья подготовлена в ходе работы в рамках программы «Научный фонд Национального исследовательского университета “Высшая школа экономики” (НИУ ВШЭ)» в 2014-2016 гг. (проект № 14-01-0177) с использованием средств выделенной НИУ ВШЭ субсидии на государственную поддержку ведущих университетов Российской Федерации в целях повышения их конкурентоспособности среди мировых научно-образовательных центров. 


\section{Введение}

Повседневная жизнь современного человека - это в значительной мере разговорная жизнь. Разговоры сопровождают нас на работе, на улице, в магазине, дома и даже когда мы оказываемся наедине с собой благодаря телефону, скайпу и мессенджерам. В условиях интенсивных социальных контактов особое значение приобретают краткосрочные разговоры при знакомстве, в которых мы должны быстро представиться, «растопить лед», узнать что-то от собеседника, сформировать хорошее впечатление, достичь взаимопонимания и каких-то взаимных соглашений. Публичные контакты, собеседования, деловые переговоры, романтические знакомства входят в обширный список данного типа разговорных ситуаций.

Несмотря на непреходящую значимость проблематики разговора, ее активная научная разработка была начата относительно недавно. Изучение актуально разворачивающегося разговора - сложная задача, вопервых, из-за множества методических и этических ограничений при работе с реальными разговорами людей, во-вторых, из-за многосложной и текучей природы самого разговора (Лабов, 1975; Трейси, Роблз, 2015). В настоящее время существует ряд подходов к изучению разговора, в рамках которых были предложены модели его анализа: этнография говорения (Хаймс, 1975), теория речевых актов (Остин, 1986), системно-функциональная лингвистика (Halliday, 1978), драматургический подход в социологии (Гофман, 2000, 2014), интеракционный процесс-ана- лиз (Bales, 1951), контент-анализ (Berelson, 1952; Gottschalk et al., 1986), дискурс-анализ (Sinclair, Coulthard, 1975), конверсационный анализ (Сакс и др., 2015).

Мы предлагаем обобщенную модель, опирающуюся на методологию конверсационного анализа. Ее мы используем для эмпирического исследования, цель которого - изучение специфических черт и структурной организации разговора при знакомстве в формате быстрых свиданий.

\section{Быстрые свидания как культурный феномен}

Одной из сложностей изучения разговоров является трудность получения, с одной стороны, полноценных по объему и качеству записей, с другой - записей, дозволительных этически для дальнейшего использования. Так, привлекательной, но хорошо защищенной крепостью выступают организационные разговоры сотрудников (совещания, разговоры в офисе, коридорах, лифтах), требующие от исследователей деликатного подхода и внутренних договоренностей (Boden, 1994, 1995). Ускользающими от исследователей оказываются такие эпизоды повседневных разговоров, как первичное публичное знакомство двух людей и личный разговор. Возможность изучения этого измерения появилась в формате «быстрых свиданий» (speed dating), возникшем в конце 1990-х гг. Он представляет собой специально организованные вечеринки, на которых люди противоположного пола знакомятся между собой, имея возможность поговорить 
за ограниченное время (4-7 минут) со множеством собеседников за вечер.

Идея быстрых свиданий возникла из обсуждения раввином Я. Дево со своими студентами способов, с помощью которых современные западные люди могут знакомиться и находить свою пару в более дружеском, безопасном формате, не затрачивая на знакомство месяцы и годы (Dеуо, Deyo, 2003). Сам Я. Дево рассматривал быстрые свидания как подход к знакомству с опорой на определенные философские и моральные принципы. К примеру, изначально этот формат предполагал, что люди не будут задавать вопросы типа «Как зарабатываешь на жизнь?» или «Где ты живешь?», так как они, по мнению Я. Дево, препятствовали более глубокому разговору и рациональноинтуитивному узнаванию собеседника (Ibid).

Первая вечеринка «быстрых свиданий» прошла в 1998 г. в ЛосАнджелесе и получила распространение по всему миру. Со временем сама идея экспресс-знакомств проникла и в другие области: быстрого нетворкинга (speed-networking), быстрых интервью (speed-interviewing) и быстрых дружеских знакомств (speed-friending) (Finkel, Eastwick, 2008).

\section{Быстрые свидания как методология исследований}

Несколько групп исследователей признают быстрые свидания не просто интересным объектом изучения, их исследование связано со многообещающей методологией (Finkel et al., 2007), которая позволяет прямым путем подойти к изучению динамики первичной романтической аттракции и развития ранних отношений, предоставляя исследователю большую батарею данных о бэкграунде участников до их реальной встречи на мероприятии, наблюдать за их общением в контролируемых условиях и даже отслеживать динамику их отношений и изменений в аттракции после события в течение дней, недель и дольше (Ibid). Этот формат имеет заметные преимущества перед ретроспективными самоотчетами людей, ограниченными факторами систематичности памяти и избирательной пристрастности (Ibid).

С точки зрения исследований выбора романтических партнеров преимущество дизайна быстрых свиданий в том, что он предоставляет данные о выборах общающихся в условиях, сходных с реальными (Fisman et al., 2006). Это сходство заключается в том, что поведение и решения участников в ходе общения сильно влияют на их реальные романтические перспективы (продолжение отношений после мероприятия), в связи с чем можно говорить о сильной экологической валидности данного дизайна (Finkel et al., 2007). Встает также вопрос валидности: насколько результаты исследований быстрых свиданий можно распространить на весь класс знакомств-разговоров? Как полагают Е. Финкель, П. Иствик и Дж. Мэттьюс, несмотря на очевидные ограничения в этом отношении быстрые свидания обладают ключевыми чертами знакомств в реальных условиях: участники оценивают других, получают оценки себя и, как в реальных условиях (бары, вечеринки, путешествия, социальные мероприятия), они одновременно 
встречают потенциальное множество романтических партнеров одновременно (Ibid). В конце концов любой отдельно взятый формат знакомств, очевидно, обладает своей спецификой: например, мы не можем утверждать, что знакомства в баре аналогичны знакомствам на домашних вечеринках (Ibid).

\section{Примеры эмпирических исследований}

За последние десять лет было проведено множество исследований быстрых свиданий. Р. Фисман с соавт. на материале специально организованных вечеринок для студентов показали, что девушки придают большое значение интеллекту и расе молодых людей, а молодые люди с меньшей вероятностью выбирают девушек, чьи интеллект и амбиции, как они полагают, превосходят их собственные (Fisman et al., 2006). Интересно также, что избирательность у девушек (среднее количество понравившихся партнеров за вечер) значительно возрастает при увеличении количества молодых людей, участвующих в быстрых свиданиях, тогда как избирательность молодых людей остается неизменной в отношении размера группы участниц (Ibid). Более поздняя работа этой же группы авторов указывает на то, что люди, выросшие в местах с относительно сильным противодействием межрасовым бракам, с большей вероятностью предпочитают на быстрых свиданиях партнеров схожей расы (Fisman et al., 2008).

Данные о гендерных предпочтениях были обобщены в более поздних исследованиях. Метаанализ
17 измерений романтической аттракции на вечеринках быстрых свиданий и спустя месяц показал отсутствие значимых половых различий в том, какой вес участники придают физической привлекательности или перспективам дохода партнеров (Finkel, Eastwick, 2008).

Р. Курзбан и Дж. Виден обобщили данные 12892 участников разного возраста (группы вечеринок 20-летних, 30-летних и 40-летних) из базы большого американского агентства быстрых свиданий и пришли к выводу, что участники выбирают себе партнеров, преимущественно основываясь на физической привлекательности и наблюдаемых чертах (вес, рост, возраст и раса), нежели на менее наблюдаемых характеристиках, таких как образование, религия или желание иметь детей (Kurzban, Weeden, 2005, 2007).

Эти притягательные внешние черты не имеют отношения к изначально заявляемым предпочтениям качеств гипотетического партнера, которые, скорее всего, оказываются верны лишь в конкретных контекстах (Kurzban, Weeden, 2007). Р. Курзбан и Дж. Виден полагают, что ситуационный контекст знакомства приводит к изменениям в неявных предпочтениях общающихся. Е. Финкель и П. Иствик предположили, что люди утрачивают точный интроспективный доступ к предпочтениям, когда встречаются вживую с партнером, что подтверждается классическими исследованиями, в которых люди оказываются неспособны дать точный отчет, почему они продемонстрировали конкретный ответ на стимул (Ibid).

Что касается гендерных различий, то они проявляются, в частности, в 
утверждениях о своих предпочтениях: говоря о своей идеальной партнерше, мужчины чаще, чем женщины, утверждают, что предпочитают физически привлекательных, а женщины чаще, чем мужчины, утверждают, что они предпочитают партнеров со стабильной перспективой дохода (Finkel, Eastwick, 2008). Также половые различия отчетливо проявляются в публикуемых рекламных самоописаниях (Kurzban, Weeden, 2007).

\section{Романтический разговор: флирт и ухаживание}

С точки зрения Е.В. Зимич, основной коммуникативной стратегией в ситуации ухаживания является стратегия гармонизащии, которая способствует установлению и поддержанию гармоничных позитивных отношений (Зимич, 2010). Она включает ряд вспомогательных стратегий: привлечения внимания и установления контакта, стремления насмешить адресата и понравиться, сокращения дистанции, официальности и устранения дискомфорта (Там же). На этапе инициации знакомства задействуются: речевые стереотипные формулы входа, выхода и поддержания контакта (формулы приветствия, прощания, обращения), мимика (улыбка, взгляд), жесты (вступления в контакт, способствующие поддержанию и усилению контакта, завершения контакта), заинтересованная интонация (Ренц, 2011). На последующем этапе оценивания друг друга партнеры обычно реализуют такие речевые жанры, как похвала, одобрение, упрек, замечание и др. (Там же).

Флирт относят к разновидности сложной и непрямой коммуникации, в которой смыслы не всегда выражаются буквально, отчего остается возможность двоякой трактовки реплик собеседника: во «флиртовом» значении и в нейтральном (Дементьев, 2006). Среди коммуникативных намерений, задействованных в подобном разговоре: стремление просигнализировать собеседнику: «Ты нравишься мне как лицо противоположного пола» - через комплименты и косвенные предложения; желание понравиться; намерение «сохранить свое лицо», избежать возможных эмоциональных потерь при вступлении в разговор; намерение «сохранить лицо» адресата (Там же).

Опираясь на анализ англоязычных записей быстрых свиданий с сайтов знакомств и уoutube.com, В.В. Фенина выделяет две ключевые стратегии, которые используют участники (Фенина, 2011). Стратегия кооперативного общения реализуется через приветствия, короткий разговорный обмен (small talk), шутки, сочувствия, согласия, коммуникативную поддержку, выражение мнения/отношения, а также через невербальные знаки - улыбки, смех, непринужденные жесты. Речевыми маркерами этой стратегии выступают вербальные и невербальные элементы, выражающие согласие, поддержку, сочувствие, интерес: «Хорошо», «Точно!», «Как ты?», «Я тоже» и др. (Там же). Вторая стратегия - гендерной аттракции - реализуется через высказывания социальной и личностной идентификации, выражение мнения/отношения, оценки собеседника, комплимент, предложение, откровенное признание. Характерные невербальные при- 
знаки: улыбки, кокетливые взгляды, жесты и движения, а также одежда, подчеркивающая гендерную принадлежность (Там же).

Отдельно описаны также повторяющиеся фреймь разговора 1 на быстрых свиданиях: (1) социальная идентификация - собеседник обращается к темам профессии, работы/ карьеры, места рождения/места жительства, семейного положения; (2) личностная идентификация - темы увлечения, свободного времени, внешности, черт характера, норм поведения, отношений между мужчиной и женщиной, секса, жизненных приоритетов (Там же). Наконец, В.В. Фенина указывает на маркеры психологчческого дискомфорта общающихся: паралингвистические элементы, такие как хезитации, речевые наполнители, неловкие паузы; синтаксическая негладкость речи: речевые повторы, незавершенные и бессвязные предложения; кинетические элементы: бегающие глаза, мимические и пантомимические движения; уход от ответа, отсутствие коммуникативной поддержки и инициативы (Там же).

\section{Анализ разговоров в рамках быстрых свиданий}

\section{Конверсационный анализ: описание метода}

Концептуальную и методологическую основу нашего исследования составлял конверсационный ана- лиз - метод систематичного описания и анализа естественно протекающего разговора в интеракции двух и более людей (Psathas, 1995; Potter, Hepburn, 2010). Согласно классическому определению, в фокусе рассмотрения этого метода оказываются негласные правила, техники, процедуры, максимы, которые используются собеседниками для воспроизводства и поддержания упорядоченности разговора (Sacks, 1984). Исследования с помощью этого метода ориентированы на детальный анализ коротких эпизодов разговорного обмена с описанием контекста взаимодействия.

Конверсационный анализ сегодня рассматривают как разновидность качественных методов исследования в психологии и социальных науках (Smith, 2003; Улановский, 2012; Бусыгина, 2013). В сравнении с другими качественными методами, многие из которых работают лишь с текстовым содержанием реплик испытуемых, конверсационный анализ работает с самим процессом взаимодействия людей и их речевыми действиями в том виде, как они производились в реальном времени и пространстве (Hindmarsh, Llewellyn, 2010). Его преимуществом также называют точность и полноту регистрации данных, которая позволяет иметь дело с человеческими практиками более прямым образом, нежели опросники, интервью или классические этнографические

${ }^{1}$ Понятие «фрейм» для анализа коммуникации и интеракции использовалось Г. Бейтсоном (Бейтсон, 2000), затем развито в работах И. Гофмана (Гофман, 2003). В целом сегодня под «фреймом» понимается рамка разговора, задающая контекст его понимания и рассмотрения (Drew, Heritage, 1992). 
заметки и наблюдения (Potter, Hepburn, 2010).

Метод возник в ходе решения Х. Саксом и его коллегами в конце 1950-х гг. чисто прикладного запроса экспертизы телефонных звонков в Центр предотвращения самоубийств в Лос-Анджелесе (Psathas, 1995). В последние два десятилетия конверсационный анализ получил распространение в социальных науках и прикладных областях, включая исследования психотерапии (Peräkylä et al., 2008), и сегодня охватывает широкий круг повседневных и институциональных разговоров - в каком-то регламентированном или специфическом ситуативном контексте: в зале суда, школьном классе, кабинете доктора, в полиции, на бизнессовещаниях, в новостных интервью, телевизионных новостях, политических речах и других медиасобытиях.

\section{Модель анализа разговора}

Х. Саксом и его последователями был разработан ряд формальных ана- литических терминов, описывающих динамику взаимодействия. Среди них такие понятия, как: «очередь в разговоре и ее смена»; «последовательность (реплик)»; «сигналы перехода очереди»; «смежные пары» (как связанные конструкции типа «вопрос - ответ», «жалоба - извинение/оправдание»; «просьба - удовлетворение/отказ» и др.); «наложения реплик» и «перебивания»; «ремонт» и «саморемонт фразы как коррекция разного рода сбоев в речи» (Сакс и др., 2015; Psathas, 1995; Турчик, 2010). Беря за основу модель Дж. Херитейджа, предназначенную для анализа институциональных разговоров (Drew, Heritage, 1992), и модифицируя ее под материал и цели нашего исследования, мы использовали обобщенную модель, включающую шесть ключевых составляющих: 1) сцена разговора; 2) дизайн разговора; 3) переходы очереди; 4) повторяющиеся паттерны; 5) коммуникативные затруднения; 6) институциональная специфика. В таблице 1 раскрывается содержание каждого элемента этой модели.

Таблица 1

\section{Рабочая модель анализа разговора}

\begin{tabular}{|l|l|}
\hline Сцена разговора & $\begin{array}{l}\text { Обстановка разговора, ситуация, время, место, дополнительные } \\
\text { характеристики }\end{array}$ \\
\hline Дизайн разговора & $\begin{array}{l}\text { Общая структурная организация разговора, общие характеристики } \\
\text { разговора }\end{array}$ \\
\hline Переходы очереди & $\begin{array}{l}\text { Специфика организации переходов очереди от участника к участ- } \\
\text { нику, перехваты инициативы, способы передачи очереди }\end{array}$ \\
\hline $\begin{array}{l}\text { Повторяющиеся } \\
\text { паттерны }\end{array}$ & $\begin{array}{l}\text { Воспроизводящиеся содержательные и интеракционные элементы } \\
\text { разговора, характерные для определенного жанра или типа разговора }\end{array}$ \\
\hline $\begin{array}{l}\text { Коммуникативные } \\
\text { затруднения }\end{array}$ & $\begin{array}{l}\text { Сложности и сбои, возникающие в разговоре, способы их преодо- } \\
\text { ления участниками }\end{array}$ \\
\hline $\begin{array}{l}\text { Институциональные } \\
\text { особенности }\end{array}$ & $\begin{array}{l}\text { Специфические черты данного типа разговоров, особенности фор- } \\
\text { мата, формы асимметрии в отношениях говорящих }\end{array}$ \\
\hline
\end{tabular}




\section{Этапы исследования}

Наше исследование проходило в несколько этапов: подготовка (реклама мероприятия, поиск и организация площадки под мероприятие, подготовка записи); отбор участников; проведение быстрых свиданий; расшифровка и анализ; описание результатов. Поиск испытуемых осуществлялся через платную рекламу в одной из социальных сетей и создание в ней специальной страницы-группы, на которой было опубликовано приглашение участвовать в вечеринке быстрых свиданий и в сопровождающем ее психологическом исследовании. Желающие должны были заполнить заявку на участие и подтвердить свою готовность к записи исследователями разговоров во время вечеринки знакомств на диктофон.

В качестве целевой аудитории рекламного объявления были выбраны студенты четырех ведущих вузов Москвы: МГУ, НИУ ВШЭ, МГИМО и Финансовой академии. Возраст участников - от 18 до 25 лет. Из всех подавших заявку случайным образом было отобрано 48 человек, по 24 человека каждого пола. Участники были поделены на две группы (24 человека, по 12 каждого пола). Для записи использовались 12 диктофонов - по диктофону на один столик для пары. Всего было проведено две вечеринки быстрых свиданий, распределенных в два дня. Время проведения одной вечеринки вместе со сбором и завершением в среднем составляло три часа. Запись велась непрерывно в течение каждого мероприятия. Совокупное время диктофонной записи разговоров за два дня составило около 28 часов.

\section{Система кодирования данных}

Для основного массива полученных в ходе быстрых свиданий записей мы использовали упрощенную расшифровку в виде текста. Для отдельных эпизодов мы использовали устоявшуюся в конверсационном анализе детальную систему кодирования, маркирующую не только реплики, но и такие паралингвистические характеристики, как интонация, громкость, темп, смех, улыбка, паузы, наложения фраз, обрывания, неразборчивость (Сакс и др., 2015; Psathas, 1995; Турчик, 2010). В таблице 2 приводится система кодирования данных.

Ниже последовательно опишем каждый из элементов предложенной модели анализа, используя систему кодирования. Имена участников, фигурирующих в выдержках из разговоров, в этических целях были изменены.

\section{Анализ результатов исследования}

\section{Сцена разговора}

Вечеринки быстрых свиданий проводились в популярном молодежном кафе в центре Москвы, в отдельном зале, в котором по кругу были расставлены небольшие столики с номерами от 1 до 12. Перед встречей были подготовлены дополнительно два зала ожидания - отдельно для молодых людей и для девушек, чтобы избежать их предварительного общения. Сам формат быстрых свиданий был стандартным: каждый раунд знакомства и свободного общения пары длился ровно 4 минуты, о которых сигнализировал ведущий; девушки 
Система кодирования данных

\begin{tabular}{|c|c|}
\hline M & молодой человек \\
\hline Д & девушка \\
\hline 个レ & повышение и понижение интонации \\
\hline . , ?! & завершающая, перечисляющая, вопросительная, восклицательная интонация \\
\hline$(-)$ & нераспознаваемая реплика \\
\hline (слово) & неточно распознаваемое слово или реплика \\
\hline${ }^{\circ}$ слово ${ }^{\circ}$ & произносимое заметно тише слово \\
\hline слово' & проглоченное слово \\
\hline слово & акцент на слове \\
\hline СЛОВО & переход на крик \\
\hline слово- & прерванное слово \\
\hline[] & наложение реплик говорящих \\
\hline$(0.0)$ & длина паузы в долях секунды \\
\hline$()$. & промежуток между высказываниями в долях секунды \\
\hline$=$ & отсутствие паузы между высказываниями \\
\hline$<>$ & замедление речи \\
\hline$><$ & ускорение речи \\
\hline : & растянутый слог и его продолжительность (например, :.::) \\
\hline$(\mathrm{x})$ & улыбка, смех и его продолжительность (например, хxх) \\
\hline$(\ldots)$ & опущенная часть высказывания \\
\hline$(())$ & комментарий исследователя \\
\hline
\end{tabular}

располагались за столиками, которые были закреплены за ними случайным образом по выбранному ими номеру; молодые люди подсаживались к ним, передвигаясь каждый раунд по кругу. В конце каждого раунда девушки и молодые люди конфиденциально заполняли карту симпатий, содержащую вопрос «Хотели бы Вы продолжить общение с этим собеседником?» В конце вечеринки организаторами традиционно выявлялись совпадения симпатий участников и в случаях взаимных совпадений парам раздавались контакты друг друга.

\section{Дизайн разговора}

Начало разговора. Стандартная последовательность начала, которая воспроизводится участниками: неформальное приветствие друг друга («привет-привет»), называние своего имени и короткие взаимные вопросы-ответы, касающиеся вуза, факультета, года обучения. В то же время существуют нетипичные способы 
старта, нарушающие и трансформирующие привычную для повседневных разговоров структуру. К ним можно отнести комментарии о ситуации «здесь и сейчас», состоянии участников, самой вечеринке или клубе как месте проведения. Пример такого начала:

M: Привет. $\boldsymbol{\vee}^{\circ}$ Я Саша. ${ }^{\circ}$ Ты заняла

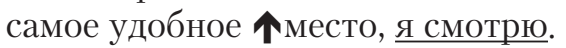

Д: Да. Мы Ћсами выбирали номераґ просто и:: (0.5) получилось, $>$ что какие-то девушки сидят в креслах, какие-то на стульях. $<$

В этом примере молодой человек приветствует девушку, не делая пауз и не передавая ход для ответного приветствия, называет себя по имени и, удерживая свою очередь, высказывается о месте-столике, за которым сидит девушка. Фактически за один ход он осуществляет три действия: приветствие, представление по имени и содержательное утверждение. Он также берет на себя инициативу во взаимодействии - задавая с первого же хода свою тему разговора («Ты заняла удобное место»), предполагая от девушки какой-то ответ. Трансформация стандартной структуры разговора проявляется в том, что ответное приветствие девушки полностью опускается, а ее представление происходит спустя несколько переходов очереди. Примерно две трети времени последующего разговора занимает обсуждение выбранной изначально темы (места расположения девушки, клуба и его особенностей), и лишь потом собеседники переходят к обсуждению места учебы и к обмену минимальными сведениями о себе. Очевидно, что такое начало знакомства является непрямым и «про- ективным»: оно не дает возможности собеседникам получить прямую информацию друг о друге, но, можно предположить, дает возможность общаться в более спонтанной манере.

«Словесная әстафета» и размер очереди. Одна из особенностей, хорошо заметная при рассмотрении готовых текстовых расшифровок,минимальный исходный размер реплик (очередей) в начале разговора и их постепенное увеличение по ходу взаимодействия. Текстовая расшифровка в этом случае напоминает форму прямоугольной трапеции, расширяющейся сверху вниз. В начале общения обычно участники дают короткие односложные ответы на реплики друг друга, быстро реагируют, как будто передавая своеобразную словесную эстафету, что отражается и на беглом темпе, и быстром смене тем:

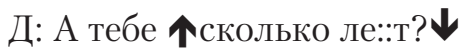

$\mathrm{M}:={ }^{\circ}$ Двадцать пять ${ }^{\circ}$

Д: Хорошо:: $\downarrow$. Мне:: девятнадцать (

М: Я старше

Д: $(\mathrm{xxx})(0.5)$ На шесть лет. А чем увлекаешься?

Вопрос - ответ - комментарий. Одна из простейших последовательностей реплик, воспроизводящаяся при знакомстве: вопрос первого говорящего, получение ответа собеседника и комментарий первого говорящего. Один из типичных примеров такой последовательности представлен в примере ниже. В нем девушка расспрашивает молодого человека, отвечавшего до этого момента короткими репликами, о его увлечениях:

Д: А зимой? > Ничего такого, лыжи?

М: Лыжи 
Д: Я никогда н не умела на лыжах кататься $\downarrow$. У меня всегда ноги вот такґвот становятся, и я падаю вперед $\boldsymbol{\downarrow}(\mathrm{xx})$

M: (1.0) Я сначала научился на коньках потом после этого ${ }^{\circ}$ на лыжах с горного склона $\downarrow^{\circ}$.

В данном примере девушка задает вопрос об опыте молодого человека, получает на него ответ и соотносит с ним свой аналогичному опыт. Можно видеть, что она создает своеобразный задел и возможность для собеседника зацепиться в своей очереди за высказанное ею в качестве ответного комментария. Из расшифровки можно также видеть, что она задействует в своем комментарии улыбки, юмор («я падаю вперед»), смех и, очевидно, демонстрацию руками («ноги вот так становятся»), после чего следует более развернутая реакция собеседника.

Поиск взаимной схожести. Поиск и поддержание взаимно общих тем то, что можно назвать одной из общих стратегий общающихся в быстрых свиданиях. Она проявляется, например, в переборе или своеобразном «скольжении» по различным темам до нахождения темы, по поводу которой каждый может чтото развернуто сказать в свою очередь. Вариантом этой стратегии является обращение и обсуждение аналогичного опыта. Ниже мы приводим начало одного из разговоров:

M: ${ }^{\circ}$ На каком курсе? ${ }^{\circ}$

Д: Ну:: сейчас на втором вообще должна быть на чет- на четвертом $\downarrow$. >Просто меня в свое время отчислилит, из-за того, что я поругались- поругалась с преподавателем $\downarrow(-)$
M: Меня тоже отчисляли $>>$ Я должен быть на втором , но сейчас на первом $\downarrow$.<

Отвечая на вопрос, девушка вводит новую тему - отмечая, что должна учиться на более старшем курсе, и упоминая причину («отчислили», «поругалась с преподавателем»). Молодой человек солидаризуется с предложенной темой и упоминает об аналогичном личном опыте, во многом повторяя конструкцию фразы девушки. Помимо этого феномена солидарности, можно также обратить внимание сразу на два сбоя и саморемонта фразы у девушки («на четвертом» и «поругалась»), что вне методологии конверсационного анализа рассматривалось бы как маркер эмоциональной нагруженности темы (Лурия, 2002).

Аналогичным образом реагирует на ту же самую историю этой же участницы уже в новом разговоре другой молодой человек: не имея опыта отчисления, он подыскивает сходный опыт «проблем» с преподавателем-аспиранткой: «Знаешь, у меня у самого были проблемы на первом курсе с аспиранткой одной. Она думала, что я ничего не знаю, а я доказывал ей, что знаю. Сдал ей экзамен на тройку». Примечательно, что в обоих представленных разговорах молодые люди жертвуют выигрышной подачей себя, свойственной для самопрезентации при знакомстве, упоминая о своих неудачах ради солидарности с историей девушки.

\section{Переходь очереди}

Перехват инициативы. Один из простых и приемлемых для обоих собеседников способов занять ини- 
циативную позицию в разговоре принятие на себя роли задающего вопросы. Вопрос, как и другие формы смежных пар, предполагает тот или иной ответ собеседника, и тот, кто задает вопросы, фактически находится в режиме модератора разговора. Один из способов перейти в этот режим - закончить уже начатую смежную пару (ответить на вопрос) и сразу начать самому новую смежную пару (задать вопрос самому). Пример такого «перехвата инициативы» рассмотрен ниже:

Д: >Нам такую задачу задал, просто вообщ::е::. (1.) Не знаю(-)

\section{М: Какую?}

Д: >(Про зерно. Что-то про зерно). Мы решаем какие-то < 个кейсы:.. (...) Он нам задал (0.5) по кейсу каждой группе. Про зерно::. Я так прочитала:: Там куча-куча вопросов, но я не особо поняла, о чем речь. Маржинальный анализ я еще поняла, (а то, он задавал нам, я почитала-). ((бодрым голосом)) Вообще чем увлекаешься?

В данном случае можно видеть распространенную ситуацию, в которой девушка отвечает на вопрос, а затем, не дожидаясь реакции собеседника, подтверждения исчерпанности темы или какого-то завершающего слова-резюме, начинает новую тему и формулирует первую часть смежной пары (вопрос). Интересно добавить, что последняя фраза девушки на момент начала разговора была самой длинной и продолжительной в обоюдных очередях. Можно предположить, что одним из стимулов переключения в режим задающего вопрос может быть «злоупотребление временем» одним говорящим, подталки- вающее его поскорее «восстановить баланс» и дать возможность собеседнику рассказать о себе или высказаться на какую-то тему. Сходным стимулом, судя по всему, может быть наблюдение за временной утратой собеседником интереса к разговору или его отвлечением на что-то другое.

Прямая передача очереди. Среди различных способов перехода и передачи очереди можно выделить прямой способ передачи, который проявляется в предложении или даже дружеской директиве («Спроси меня о чем-нибудь») либо в косвенном намеке-замечании («Что-то я много говорю»). Этот сценарий подобен переключению разговора из режима «автопилота» и спонтанного течения в «ручной режим» управления. Как видно из эпизода, приведенного ниже, такая прямая передача очереди и инициативы может вызывать коммуникативные сбои, так как собеседник, которому передается слово, может оказаться не готов в тот момент что-то предложить. Этот сбой может проявляться в более продолжительных паузах, смехе, комментариях про то, что человек не знает, что спросить:

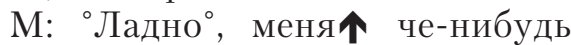
поспрашивай тоже.

Д: $(\mathrm{xxx})(2.0)$ А че поспрашивать? (1.0) А: не знаю (0.5). >Фильмы, книги, театр, музыка $<$ [Что-нибудь из этого-

$\mathrm{M}$ :

[Да::, все::, кроме книг. >Вообще не нашел себя в этой жизни как читающую личность. $<$

В этом эпизоде молодой человек после активного расспроса девушки внезапно отдает инициативу и предлагает ей расспросить его о чем-либо. 
Девушке потребовались пауза и переход из режима рассказчика в режим задающего вопрос («а че поспрашивать?», «не знаю»). Не имея готового вопроса и готовой темы для обсуждения, она перечисляет обобщенные области хобби, призывая собеседника самому выбрать и развить какуюто из этих тем.

Перевод темь как уход от конфронтации. Смена темы разговора еще один универсальный способ управления ходом разговора и очередностью (Coulthard, 1985). В идеальной модели интеракции темы сменяются, когда оба или один собеседник считают ее обсуждение исчерпанным. Однако в живом процессе общения это происходит, очевидно, гораздо менее рациональным, согласованным образом. Отдельно можно выделить случаи, когда перевод темы выполняет какую-то дополнительную интеракционную функцию: например, ухода от конфронтации. Ниже мы приводим самое начало разговора, в котором участники поприветствовали друг друга и спросили о месте учебы.

М: Факультет?

Д: Юридический $\downarrow$

М: ${ }^{\circ}$ Вээ:мка ${ }^{\circ}$

Д: Какой?

М: Вээ:мка::^

Д: Мы вас- (0.3) >Блин, никогда не забуду наш первый фина::.:л. ${ }^{\circ}$ Кубок ${ }^{\circ}$ Кавээ::н, это было три года назад. Мы вас порвали в первых трех раундах, а четвертый у нас был не готов вообще, из-за этого вы выиграли кубок.

M: $(\operatorname{xxxxx})(1.5)$

Д: Я 个очень зла на ваш [факультет. $\mathrm{M}$ : $[>\mathrm{A}$ ты на каком курсе?<
Можно заметить, как, получив ответ о факультете молодого человека («ВМК»), девушка переспрашивает его, что, как мы еще увидим, само по себе примечательно: переспрос предшествует иногда высказыванию собеседником своего отношения к заявленной теме. Далее девушка делает фальстарт экспрессивной фразы («Мы вас...»), останавливает себя и начинает с предыстории («Блин, никогда не забуду наш первый финал»). Потом она снова возвращается к незавершенной фразе («Мы вас порвали»), смягченной немного игровым тоном. Молодой человек реагирует на эту реплику смехом, очевидно придавая реплике девушки еще в большей степени рамку «шутки» и используя то, что Г. Джефферсон называет «техникой приглашения к смеху» (Jefferson, 1979). Девушка не поддерживает смех своим ответным смехом и добавляет еще более прямой конфронтирующий комментарий («Я очень зла на ваш факультет»). На конец этой фразы молодой человек накладывает свой вопрос, переводящий разговор на другую тему и возвращающий продолжение знакомства («Ты на каком курсе?»). С учетом контекста этот резкий перевод можно рассматривать как способ ухода молодого человека от конфронтации, пусть даже не реальной, а игровой (что слышно по интонации девушки и последующему контексту ее реплик).

\section{Повторяющиеся паттернь}

Можно выделить ряд типовых тем, вокруг которых вращаются анализируемые разговоры. Ключевые 
темы: учебы, вуза, факультета, специальности, студенческой жизни, будущего, планов, хобби, путешествий, работы, быстрых свиданий, мотивации участия в них. Помимо самих тем, можно выделить и более локальные повторяющиеся паттерны взаимодействия, такие как шаблонные цепочки реплик и готовые шаблоны фраз.

Шаблонные цепочки взаимодействия. В материале разговоров быстрых свиданий можно обнаружить эпизоды, в которых один заданный вопрос приводит в жизнь целую цепочку вопросов-ответов, структурно повторяющихся у одного участника из разговора в разговор с разными людьми. Если сравнивать подобные цепочки между собой, то можно заметить, как с первым собеседником они конструировались, занимали больше времени и поясняющих фраз. В последующих разговорах они сокращались и оптимизировались, все больше превращаясь в готовый шаблон. Ниже мы приводим не реальную расшифровку, а уже обобщенную схему, описывающую несколько схожих случаев развития разговора одной из девушек с несколькими молодыми людьми.

М: Что занимаешься в свободное время?

Д: Танцами.

M: Какими именно танцами?

Д: Все, что танцует партнер.

M: Например?/Самое любимое?

Д: Сейчас в основном клубную латину, бачата и т.д.

Спусковым механизмом в этой цепочке оказывается достаточно стандартный вопрос о том, чем девушка занимается в свободное время. Далее ответы девушки задают определенную логику и направление разговора. Во множестве разговоров быстрых свиданий можно отследить наличие таких цепочек из нескольких вопросов-ответов: шаблон из 2-3 повторяющихся последовательных смежных пар. Интересно, что в этом случае с формальной точки зрения беседой управляет молодой человек, задающий вопросы, однако подлинное направление разговора в данном случае задает своими ответами именно девушка. Ее ответы подсказывают и подводят к «правильному» следующему ходу молодого человека. Можно сказать, что в этом случае девушка выступает «серым кардиналом» разговора. Молодой же человек, задав определенный вопрос, сразу попадает в «капкан» заготовленного шаблона и делает дальше предсказуемые шаги. Оговоримся, что это касается только подобных коротких цепочек и они не имеют гендерной специфики, так как присутствуют и в репликах молодых людей.

Готовые шаблоны фраз. Помимо описанных цепочек взаимных реплик, существуют также индивидуальные фразовые заготовки. При индивидуальном анализе разговоров каждого отдельного участника с разными собеседниками можно заметить формулировки, которые, как некая «мантра», повторяются с минимальными обновлениями в зависимости от контекста. Ниже мы приводим пример повторяющегося ответа-шутки девушки в разных раундах с двумя разными молодыми людьми:

(1)

М: $\uparrow<$ Ты хорошо сидишь $\downarrow$. У

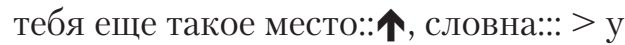


тебя молодой человек сидит на допросе. Под такой лампой

Д: =Нет, знаешь, я представляла себе это не допро::с А мне кажется это такое (1.0) ((пониженным тоном)) Вы принеслиґ деньги? Товар здесь $\downarrow$. > Такой знаешь мафио::зи, я не знаю, покер, оружие, наркотики там< убийства::

(2)

M: ${ }^{\circ}$ Тут (как) на допросе, ес:: чесно ${ }^{\circ}$.

Д: Не, знаешь, >не на допросе, напоминает это такая мафио::зи. (пониженным тоном) Вы принеслиґ деньги? Товар у меня $\downarrow$.

$\mathrm{M}:(\mathrm{xx})$

Д: =У этого:: у: следователя такие насто::льные лампы. (-) Я просто работаю в полиции.

В обоих случаях молодые люди с самого начала разговора описывают свои впечатления о месте, в котором сидит данная девушка, сравнивая его с местом для допроса (над столом висит яркая лампа). Можно видеть, что структура ответа девушки в обоих случаях одинакова: она содержит отрицание-несогласие с репликой собеседника («нет», «не»), предложение собственного фрейма («мафиози»), игровой вызов-требование («Вы принесли деньги?»). Далее в одном случае девушка развивает игровой угрожающий сценарий («Покер, оружие, наркотики, убийства»), в другом - переходит к новой, биографической линии (работа в полиции).

Сравнивая разговоры одного человека с разными собеседниками, можно утверждать, что, с одной стороны, у говорящего обычно имеются индивидуальные фразовые и интеракционные заготовки, которые повторяются и в которые он иногда вовлекает собеседников как в своеобразную «воронку разговора»; с другой стороны, каждое новое взаимодействие вносит свою «нелинейность», непредсказуемость и вариацию.

\section{Коммуникативные затруднения}

Недопонимание и смягчающие действия. Одной из интересных областей анализа выступают сложности, возникающие по ходу разговора, и способы, с помощью которых говорящие выходят из них. Недопонимание из-за многозначности одна из таких затруднительных ситуаций. Ниже мы приводим один из способов выхода из нее - через использование смеха и смягчающих реплик:

Д: А та:::к я танщую

M: (0.4) Тоже танцуешь? (0.5) В смысле (хxх)

Д: (xxx) Не оригинально (.) я [понимаю- ( $\mathrm{xxx})$

$\mathrm{M}$ : [не.......: $\uparrow(\operatorname{xxxxx})$ нет $\downarrow$ я не в этом смысле (.) просто (0.5) просто (0.5) ну все танцуют как бы (.) или ты занимаешься::-

\section{Д: Не::т $\downarrow$ я занимаюсь \\ M: A:..: (x)}

Можно видеть, что в этом эпизоде смягчающими временное недопонимание действиями собеседников стали улыбка, смех, пояснение слушателем своей реакции и ответ на пояснение. Если представлять обобщенную структуру приведенного разговорного обмена, ее можно изобразить последовательностью: (1) Многозначная 
реплика девушки - (2) Демонстрация недопонимания молодым человеком и Смех - (3) Смех и Пояснение девушки - (4) Демонстрация восстановленного согласия молодым человеком.

Игнорирование чужих ошибок. Разного рода ошибки собеседника (оговорки, подмены фактов, незнание, неудачные формулировки) достаточно частые элементы разговора. Интересно отследить, что делают оба собеседника, сталкиваясь с ошибкой другого. Существует множество способов реакции на ошибку: проигнорировать ошибку собеседника; исправить ее вне свой очереди, прервав говорящего; исправить ее при переходе слова в рамках своей очереди говорения; исправить и сделать паузу, предоставив свободу говорящему для выбора следующего действия; акцентировать ошибку и создать необходимость для собеседника признания ее и какого-то комментария; и т.д. В приводимом ниже примере мы встречаемся с ситуацией, в которой есть ошибка, правка вне очереди с наложением фраз и возвращение к разговору. В разговоpe девушка говорит об одном из своих увлечений:

Д: Я была дебютанткой на Венском балу в Москве $(. .$.

M: Ро:::российское все:: даґ то есть все было?

или Венеция [и как бы все-таки-]

Д: [мм::: нет! Вена 个не Венеция! Ну::: Австрия]

M:

Вена $\downarrow$ (.) пардон (.) да]

Д: Нет个(.) просто возрождение (.) не обязательно русских $\downarrow$ вообще=возрождение' этих балов и так далее.
Задавая вопрос, молодой человек вместо «Вены» говорит «Венеция». Девушка, не дожидаясь завершения фразы, поправляет его («нет! Вена, не Венеция!»). Молодой человек, также не дожидаясь полной завершенности поправки/очереди девушки и говоря внахлест ее реплики, признает свою ошибку и поправляется: он повторяет правильное слово и извиняется. Начало следующей фразы девушки («Нет»), очевидно, относится к этому извинению демонстрации отсутствия проблемы для девушки. Далее она отвечает на вопрос, прозвучавший в предыдущей очереди молодого человека («Возрождение не обязательно русских балов»). Можно видеть, что в данном случае ремонт фразы девушка осуществляет мимоходом: она быстро поправляет собеседника и продолжает развивать свою мысль, не останавливаясь на ошибке как на новой мини-теме разговора, что иногда происходит в разговоре. С точки зрения динамики интеракции девушка в этом мини-эпизоде помогает молодому человеку «сохранить лицо» и контакт.

Запинки и динамика разговора. Повседневный разговор изобилует разного рода запинками и оговорками, которые обычно воспринимаются говорящими по ходу взаимодействия как шум: им обычно не придается большого значения говорящими, и они не рассматриваются в качестве сколько-нибудь значимых факторов для динамики разговора. Тем не менее материал живых разговоров дает примеры, когда мимолетные сбои начинают определять дальнейший ход разговора. В приводимом ниже примере молодой человек 
спрашивает девушку о вузе и факультете:

М: Где:: учишься::?

Д: $\underline{\text { Мгимо }} \downarrow$ (хx)

M: >Отлично! = Какой $\downarrow$ факультет? <

Д: Междуна -э::.:: Международного права $\downarrow$ (х). >=Я просто за седня (хx) стока раз это уже сказала, что начинаю заговариватьcя $\downarrow$ (xx)

В этом примере девушка оговаривается, поправляет себя и, не передавая своего хода собеседнику, сразу же дает поясняющий комментарий относительно этого сбоя («За сегодня столько раз это уже сказала, что начинаю заговариваться»). Примечательно, что далее молодой человек отталкивается именно от этого пояснения, предлагая тему для дальнейшего развития разговора:

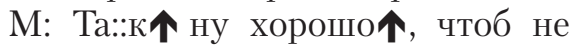
повторять предыдущи:::х. $>$ О чем еще $<$ не говорили. $\downarrow$ О путешествиях говорили?

Д: =Нет. $(\mathrm{xx})$

M: =Давай. $\downarrow$ Любишь ствовать?

Как видно, молодой человек солидаризуется («Ну хорошо») и принимает в расчет фразу девушки о множестве повторов в разговорах с предыдущими собеседниками («Чтоб не повторять предыдущих»), ища новую тему («О чем еще не говорили?»). То, что для девушки было способом объяснения своего едва заметного речевого сбоя, для молодого человека становится ориентиром в разговоре. Структуру эпизода можно представить схематически: (1) Запинка девушки - (2) Саморемонт фразы девушкой - (3) Объяснение девушкой причин оговорки - (4)
Согласие и принятие объяснения молодым человеком - (5) Предложение выбрать новую тему молодым человеком. Обобщая анализ этого эпизода, можно отметить удивительную игру и динамическую связь факторов различной природы: предполагаемого состояния говорящего, повлекшего, по его собственному мнению, непреднамеренный сбой в речи; стремление говорящим сохранить лицо (комментарий о причине сбоя); принятие отвечающим за ориентир этого комментария и его стремление учесть его в дальнейшем выборе направления разговора.

Переспрос в «сложных местах». Феномен переспрашивания говорящего проявляется часто в местах тихих реплик, повышенного внешнего шума (громких накладывающихся реплик участников за другими столиками), наложения очередей собеседников друг на друга, редуцированных в артикуляции слов говорящего. В то же время можно идентифицировать места разговора, сложные или ответственные с точки зрения темы, в отношении которых участники используют переспрос. Ниже девушка отвечает на вопрос о своих увлечениях:

Д: На данный момент я:: стриппластикой (xx) занима[юсь.

M: [Да? Стрип-пластикой?]

Д: =Да. $\downarrow$ Стрип-пластикой.

М: Прикольно. $\downarrow$ Почему?

Д: Нравится

М: Да?

Д: =Ну это

М: =Это красиво. $\downarrow>$ Многие просто:: это очень к легкому относят поведению, но это их ошибка.个 =Я считаю, это (намного) красивое 
такое. Это надо понять. $=$ Просто знаешь, из-за малоумия. $\downarrow<(\ldots)$.

Молодой человек реагирует на реплику девушки целой серией вопросов. Он переспрашивает ее, прерывая и удостоверяясь, правильно ли он расслышал реплику о ее занятии стрип-пластикой. Далее следует еще один вопрос («Почему?»), на который он получает быстрый лаконичный ответ («Нравится»), и снова переспрашивает («Да?»). Получив еще раз ответ («Ну это правда красиво»), он практически мгновенно поддерживает девушку согласием с утвердительной интонацией («Это красиво»). И далее он быстро делает комментарий, первая часть которого, очевидно, поясняет его предыдущий расспрос («Многие просто это к очень легкому относят поведению»), а вторая - проясняет его собственное отношение к занятию стрип-пластикой («Я считаю, это красивое»). Можно сказать, что переспрос здесь выступал формой проверки правильности адресата перед высказыванием своего отношения к заявленной собеседником теме. Отметим здесь также наличие в этом комментарии множества сбоев и общую несогласованность фраз, что вне рамок конверсационного анализа могло бы интерпретироваться как аффективно-заряженный эпизод (Лурия, 2002).

\section{Институциональная спечифика}

Конвейерность взаимодействия. Разговор-знакомство на «быстрых свиданиях» институционален, и, как и все институциональные разговоры (разговор в зале суда, у школьной доски), по сравнению с условно сво- бодным повседневным разговорным обменом, по-своему ограничен и специфичен. К отличительным чертам можно отнести, прежде всего, «конвейерность» происходящих знакомств, разговоров, постоянную смену партнеров каждые четыре минуты.

Перенос содержания и отложенное реагирование. С этой конвейерностью и быстрой сменой партнеров по общению, очевидно, связан и феномен привнесения тем и эпизодов, обсуждавшихся с одними участниками, в разговоры с новыми участниками. Они используются, например, для своеобразного отложенного отреагирования по отношению к каким-то репликам предыдущих собеседников. Например, девушка упоминает в разговоре с новым собеседником только что завершенный разговор и реплику предыдущего партнера: «Прикинь, чувак сказал, что юристы - это фигня!»

«Телеграфный стиль». Можно также отметить особый стиль представления, проявляющийся в быстром, сжатом, сокращенном, не содержащем дополнительных пояснений сообщении ключевых сведений о себе. Ниже мы приводим яркий пример такого стиля:

М: Привет (xх)

Д: Приве::(хx)т $\uparrow(\mathrm{xxxxxxx)}$

(1.5) ((оба смеются))

М: Я Стас, и::.:: я:::: не знаю’ я наверное всем и каждому буду говорить что мне > 19 лет, я учусь на экономиста, я:: люблю рисовать, я:: занимаюсь плаванием, я:.: и так далее <

Д: (1.0) Здорово (хx)

M: Ну просто:: мне кажется::^ э::то стоит ужать $\uparrow$ до знаешь до минимума $\downarrow$ чтобы сразу понять (.) а ты::? 


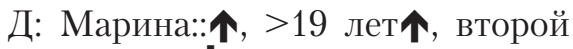
курс МГИМО факультет международного права::^<

Как можно видеть, молодой человек называет себя по имени и, не передавая хода собеседнице, называет кратко и в быстром темпе свой возраст, специальность, хобби, т.е. данные, о которых участники обычно говорят друг с другом в вопросноответной форме в первой части разговора. Таким образом, он сокращает фазу представления себя, о чем говорит позже. По небольшой паузе девушки и ее короткому ответу без развития темы («Здорово») можно заметить некоторую заминку в ее реакции на такое представление молодого человека. Ответом на это становится поясняющий комментарий молодого человека («Просто мне кажется, это стоит ужать»). После чего девушка отвечает более развернуто по «телеграфному» шаблону, заданному молодым человеком: имя, возраст, курс, вуз, специальность.

Отсутствие закрытия разговора. В разговорах на быстрых свиданиях отсутствует такой привычный элемент взаимодействия, как завершение/закрытие разговора (типа «До свидания - До свидания»; «Пока Пока»), завершение начатых реплик, историй и смежных пар (например, заданный вопрос, на который собеседник не успевает ответить). По правилам данного формата конец разговора определяют не сами участники разговора, а ведущий, подающий сигнал (в нашем случае это был звонок колокольчика), после которого участникам необходимо прерваться, заполнить «анкету симпатий» и пересесть к следующему собеседнику. Интересно, что, даже несмотря на регламент, участники все равно стремятся тем или иным образом завершить разговор после звонка. В частности, они используют резюмирующие фразы типа «Говорила в основном ты», «Видимо, эту историю я уже не услышу» и т.п.

Гендерная асимметрия. Говоря об асимметрии в отношениях на быстрых свиданиях, можно упомянуть лишь о небольшой гендерной асимметрии, заданной правилом перемещения участников. Перемещаются обычно молодые люди, а девушки остаются за своими столиками. Это привносит, на наш взгляд, свою специфику в позиции, с которых выступают оба участника. Девушки в этой модели оказываются «принимающей стороной» или «хозяйками» столиков, за которыми находятся, молодые люди - приходящими и сменяющими друг друга «гостями». Как мы видели, это может становиться темой обсуждения (выбор места, столика, небольшие различия в мебели, освещении), но более весомо в данном случае то, что это ставит молодых людей в неравные условия по сравнению с девушками. Эта форма асимметрии очевидным образом отсылает нас к более широкому контексту - обсуждению культурных ожиданий и представлений о том, кто должен выступать инициатором и активной стороной в романтическом знакомстве.

\section{Выводы и обсуждение результатов}

Представленные фрагменты имеют отношение к различным уровням и аспектам разговора: общие стратегии говорящих (типичное и нестан- 
дартное начало, ориентация на поиск взаимной схожести); тематика разговоров (учеба, планы на будущее, увлечения, мотивация участия в быстрых свиданиях, место проведения); способы ведения и передачи слова (перехваты, прямая передача, перевод темы); структурные особенности взаимодействия (удлинение по ходу разговора размера очереди, использование структуры «вопрос ответ - комментарий»); динамика взаимодействия (влияние небольших сбоев на ход разговора), индивидуальные паттерны (фразовые заготовки и шаблонные цепочки взаимодействия), способы выхода из затруднений (смягчения, игнорирование чужих ошибок, переспрос в сложных местах), специфические черты разговора в быстрых свиданиях (конвейерность взаимодействия, телеграфный стиль, перенос содержания из других разговоров и отложенное реагирование, отсутствие закрытия разговора, элемент гендерной асимметрии).

В материале собранных разговоров очевидным образом отражается возрастная специфика выборки студенческая аудитория быстрых свиданий. Это заметно в темах обсуждения (учеба, планы на будущее, увлечения). Наши участники также фактически не говорили напрямую на романтические темы, не проявляли открыто свою симпатию и минимально использовали комплименты. Это отличает их от участников быстрых свиданий более старших возрастных групп, в общении которых распространены флирт, прямые комплименты, сексуальные шутки и даже откровенные предложения сексуального характера (Фе- нина, 2011). В этом смысле если говорить о присутствии стратегии гендерной аттракции в рассматриваемых нами разговорах, то в очень неявном, маскируемом виде. Мы назвали это жанром косвенной симпатии, когда симпатия фактически никак не выражается вербально и проявляется скорее в общей организации гладкого, гармоничного разговора, а также невербально через улыбку, смех, мимику, жесты, позу.

Еще один вопрос, который поднимает исследование, - о месте индивидуальных разговорных шаблонов при знакомстве. Мы обладали уникальной возможностью сравнивать разговор каждого отдельного собеседника с разными партнерами: отслеживать повторы, переносы тем, изменения на старте, различия в самопрезентации, стиле. Записи показывают наличие повторяющихся из раунда в раунд индивидуальных разговорных шаблонов: одни и те же вопросы к собеседнику (например, просьба девушки к юношам назвать свое самое плохое качество), одни и те же ответы (например, стереотипная реплика про занятие танцами), шаблонные цепочки реплик. Использование этих заготовок подобно вовлечению другого человека в свою «орбиту» тем, стиля, дебатов или «воронку» разговора. Можно также наблюдать характерные для каждого участника типы речевых и поведенческих действий в интеракции (Bales, 1951): стремление участника больше задавать вопросы или, наоборот, больше слушать, или строить разговор остро, в определенной мере конкурировать, или же обмениваться взглядами. Наконец, можно заметить индивидуальные 
стилевые особенности речи: предпочитаемую скорость, громкость говорения и т.п.

Остаются ли неизменными эти шаблоны и стили из разговора в разговор? Один из выводов в результате исследований реальных разговоров в повседневных ситуациях заключается в том, что вне зависимости от наших исходных заготовок взаимодействие с другим человеком неизбежно задает свое направление (Boden, 1995). Так, каждый рассматриваемый нами разговор неизменно обновлялся и обрастал новыми темами, а используемые шаблоны, как мы видели, помещались в разный контекст и имели вариации. В этом смысле даже схожие реплики и шаблоны были «повторением без повторения», подобно тому как и стереотипные движения (типа беговых или ударных) не являются при ближайшем рассмотрении буквальным повторением предыдущих (Бернштейн, 1997).

Разговор также предстает перед нами как гибкий и помехонеустойчивый процесс. Как видно из материалов и анализа, он изобилует мелкими событиями и сбоями (оговорки, запинки, паузы), остающимися обычно вне внимания говорящих, но фактически участвующими в построении динамики разговора. Оговоркам и запинкам традиционно придавалось большое внимание в психологической практике со времен Фрейда с точки зрения их скрытого мотивационного значения для говорящего (Фрейд, 2006). Конверса- ционный же анализ через пошаговый мониторинг развития разговора помогает отследить эффект оговорок на судьбу разговора: выбор и изменение тем, характера интеракции, статуса говорящих и пр.

\section{Ограничения исследования}

Отмечая ограничения исследования, оговоримся, что выделенные выше особенности разговора не исчерпывают многообразия стратегий, тем и паттернов, фигурирующих в общении на происходивших быстрых свиданиях. Следует также учитывать возраст и социальный статус участников исследования (студенты 18-25 лет), которые задавали специфику тем обсуждения. Можно также указать на ограничение конверсационного анализа в отношении утверждений о намерениях, мотивах, убеждениях и состояниях говорящих ${ }^{2}$, что является способом избегания неочевидных суждений о разговоре (Heritage, 2008; Hindmarsh, Llewellyn, 2010). Наконец, участники знали, что их разговоры записываются и будут анализироваться, это могло дополнительно оказывать влияние на их взаимодействие, хотя интенсивность общения и частая смена собеседников, очевидно, в какой-то мере снижали контроль за разговором, а само его наличие не избавляло от решения экстралингвистических задач, лежащих в основе разговора при знакомстве: налаживание контакта, самопрезентация, стремление понравиться, получить в

\footnotetext{
${ }^{2}$ Исключения составляют те случаи, когда это может быть явно продемонстрировано в самом материале и когда участники сами на это указали в ходе своего взаимодействия (Psathas, 1995).
} 
конце выбор, сделать собственный выбор.

\section{Заключение}

Представленный анализ позволил нам описать общую организацию разговора при знакомстве и отдельные разговорные феномены различной сложности, уровня и природы. Мы также стремились представить рабочую модель анализа разговора, которая, как нам кажется, удобна для анализа повседневных и институциональных разговоров в полевых этнографических условиях. Говоря о перспективе дальнейших исследований, мы хотели бы указать на феномен, наглядно проявившийся в уже представленных материалах. Это феномен лидерства в парном или групповом разговоре, отражающий то, кто и как инициирует взаимодействие, кто и как им управляет и его модерирует, кто отвечает за смену тем и очередей, кто и как резюмирует и завершает разговор. Как нам представляется, детальный разбор этих и других феноменов живого повседневного взаимодействия может приблизить нас к более полному и глубокому пониманию фундаментальных и прикладных проблем психологии, психотерапии, социальных отношений и коммуникаций.

\section{Литература}

Бейтсон, Г. (2000). Экология разума. Избранные статьи по антропологии, психиатрии, эпистемологии. М.: Смысл.

Бернштейн, Н. А. (1997). Биомеханика и физиология движений. Воронеж: НПО «МОДЭК».

Бусыгина, Н. П. (2013). Методология качественных исследований в психологии. М.: ИНФРА-М.

Гофман, И. (2000). Представление себя другим в повседневной жизни. М.: Канон-Пресс.

Гофман, И. (2003). Анализ фреймов: эссе об организации повседневного опьта. М.: Институт социологии РАН.

Гофман, И. (2014). Порядок взаимодействия. Социология власти, 1, 163-199.

Дементьев, В. В. (2006). Непрямая коммуникация. М.: Гнозис.

Зимич, Е. В. (2010). Структурно-семантические и прагматические особенности организации коммуникативной ситуации ухаживания. Вісник Харківського національного університету імені В.Н. Каразіна. Серія «Романо-германська філологія. Методика викладання іноземних мов», 930(64), 104-109.

Лабов, У. (1975). Исследование языка в его социальном контексте. В кн. Н. С. Чемоданов (ред.), Новое в лингвистике (вып. 7, с. 96-181). М.: Прогресс.

Лурия, А. Р. (2002). Природа человеческих конфликтов: объективное изучение дезорганизации поведения человека. М.: Когито-Центр.

Остин, Дж. Л. (1986). Слово как действие. В кн. Б. Ю. Городецкий (ред.), Новое в зарубежной лингвистике (вып. 17, с. 22-129). М.: Прогресс.

Ренц, Т. Г. (2011). Романтическое общение в коммуникативно-семиотическом аспекте (Автореферат докторской диссертации, Волгоградский государственный педагогический университет, Волгоград).

Сакс, Х., Щеглофф, Э., Джефферсон, Г. (2015). Простейшая систематика организации очередности в разговоре. Социологическое обозрение, 14(1), 142-202. 
Трейси, К., Роблз, Дж. (2015). Повседневный разговор. Строение и отражение идентичности. Харьков: Гуманитарный центр.

Турчик, А. В. (2010). Конверсационный анализ речевого взаимодействия в ситуации исследовательского интервью (Кандидатская диссертация, Российский университет дружбы народов, Москва).

Улановский, А. М. (2012). Феноменологческая психология: качественные исследования и работа с переживанием. М.: Смысл.

Фенина, В. В. (2011). Speed dating: новый формат речевого жанра знакомство (на материале английского языка). В кн. В. В. Дементьев (ред.), Жанры речи. Жанр и языковая личность (с. 287-302). Саратов: Издательский центр «Наука».

Фрейд, 3. (2006). Психопатология обыденной жизни. М.: Азбука-классика.

Хаймс, Д. (1975). Этнография речи. В кн. Н. С. Чемоданов (ред.), Новое в лингвистике (вып. 7, c. 42-95). М.: Прогресс.

Ссылки на зарубежные источники см. в разделе References после англоязыного блока.
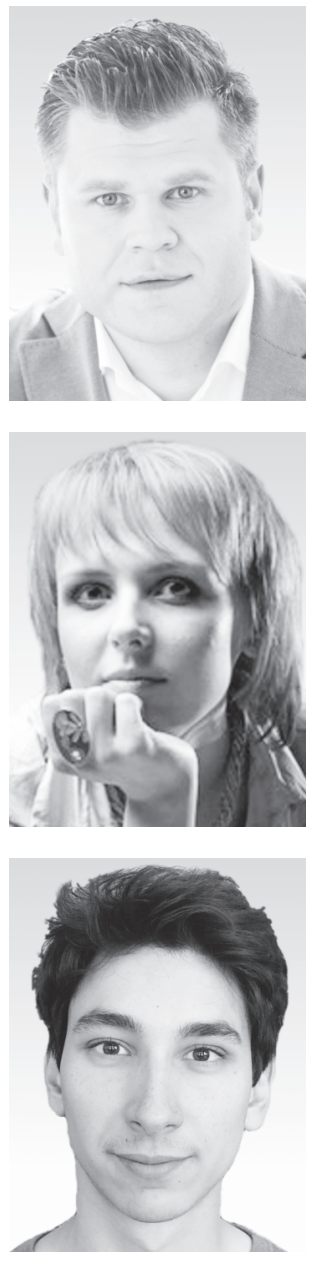

Улановский Алексей Маркович - доцент, факультет социальных наук, Национальный исследовательский университет «Высшая школа экономики», кандидат психологических наук.

Сфера научных интересов: анализ разговоров, внутригрупповая коммуникация, лидерство, организационное консультирование.

Контакты: a.m.ulanovsky@gmail.com

Ерохина Людмила Алексеевна - специалист-психолог, филолог, аспирант, Институт русского языка РАН.

Сфера научных интересов: психолингвистика, лингвистический анализ текстов, анализ разговоров.

Контакты: erokhina_ludmila@inbox.ru

Ян Микаэл Давидович - психолог, основатель проекта ManyChat. Сфера научных интересов: психология общения, информационные технологии, бизнес-коммуникация, разговорная коммерция, чат-боты. Контакты: mike@manychat.com 


\title{
The Talk during a Meeting: Conversation Analysis of Speed Dating
}

\author{
Alexey M. Ulanovsky ${ }^{a}$, Ludmila A. Erokhina ${ }^{\mathrm{b}}$, Mikael D. Jan \\ ${ }^{a}$ National Research University Higher School of Economics, 20 Myasnitskaya Str., Moscow, 101000, \\ Russian Federation \\ ${ }^{b}$ Russian Language Institute of Russian Academy of Sciences, 18/2 Volkhonka Str., Moscow, 119019, \\ Russian Federation
}

\begin{abstract}
The article is dedicated to the analysis of talks during acquaintance on the content of recordings of speed dating. The issue of research of the romantic discourse is taken into account. The format of speed dating is described, which is not only a unique cultural and socio-psychological phenomenon and a special genre of dialog, but is also regarded as a promising methodology of communication, interpersonal relationships and attraction studies. The review of studies, based on this methodology is presented. Special consideration is given to the method of conversation analysis, created by H. Sacks et al. at the end of the 1950s to solve applied problems of expertise in phone-calls, which belongs to the group of qualitative methods of research in social sciences and is oriented to the detailed analysis of short episodes of talks of the two or more interlocutors. A model of analysis of mundane talks is proposed, which includes elements of the scene-context, the general design of the talk, ways to change the sequence of speech, recurring patterns, communicative difficulties and institutional specifics of the talks. The results of empirical research on young people $(\mathrm{N}=48)$ during the process of acquaintance at the speed dating parties is presented. The phenomena of talks in this situation are found and described: typical and atypical ways to start the talk, the increase in the size of the turns during the communication, pattern "question-answer-commentary", the search for mutual similarities as a strategy of the talkers, recapturing of initiative, the direct transference of the turn, the change of the theme as a way to avoid confrontation, speech patterns to soften misunderstanding, hesitations and their influence on the talk, clarifications, the conveyor of the interaction, the transference of content and postponed reaction, the "telegraphic style", the lack of finishing lines in a dialog, the gender asymmetry of the interaction.
\end{abstract}

Keywords: conversation, interaction, conversation analysis, meeting, speed dating.

\section{References}

Bales, R. F. (1951). Interaction process analysis: a method for the study of small groups. Cambridge, MA: Addison-Wesley.

Bateson, G. (2000). Ekologiya razuma. Izbrannye stat'i po antropologii, psikhiatrii, epistemologii [The ecology of the mind: Selected essays in anthropology, psychiatry, epistemology]. Moscow: Smysl. (Transl. of: Bateson, G. (1972). Steps to an ecology of mind: Collected essays in anthropology, psychiatry, evolution, and epistemology. New York: Ballantine Books).

Berelson, B. (1952). Content analysis in communication research. Glencoe, IL: Free Press. 
Bernshtein, N. A. (1997). Biomekhanika i fiziologiya dvizhenii [The biomechanics and the physiology of movements]. Voronezh: NPO "MODEK".

Boden, D. (1994). The business of talk. Cambridge: Polity Press.

Boden, D. (1995). Agendas and arrangement: Everyday negotiations in meetings. In A. Firth (Ed.), Discourse of negotiations: Studies of language in the workplace (pp. 83-100). Oxford, UK: Pergamon.

Busygina, N. P. (2013). Metodologiya kachestvennykh issledovanii v psikhologii [The methodology of the qualitative research in psychology]. Moscow: INFRA-M.

Coulthard, M. (1985). An introduction to discourse analysis (2nd ed.). London: Longman.

Dementiev, V. V. (2006). Nepryamaya kommunikatsiya [Indirect communication]. Moscow: Gnozis.

Deyo, Y., \& Deyo, S. (2003). SpeedDating: A timesaving Guide to finding your lifelong love. New York: HarperCollins.

Drew, P., \& Heritage, J. (1992). Analyzing talk at work: an introduction. In J. Gumperz (Ed.), Talk at work: interaction in institutional settings (pp. 3-65). Cambridge: Cambridge University Press.

Fenina, V. V. (2011). Speed dating: novyi format rechevogo zhanra znakomstva (na materiale angliiskogo yazyka) [Speed dating: The new format of the speech genre of acquaintance (on the material of the English language)]. In V. V. Dementiev (Ed.), Zhanry rechi. Zhanr i yazykovaya lichnost' [Genres of speech. The genre and the lingual personality] (pp. 287-302). Saratov: Izdatel'skii Tsentr "Nauka".

Finkel, E. J., \& Eastwick, P. W. (2008). Speed-dating. Current Directions in Psychological Science, 17(3), 193-197.

Finkel, E. J., Eastwick, P. W., \& Matthews, J. (2007). Speed-dating as an invaluable tool for studying romantic attraction: A methodological primer. Personal Relationships, 14, 149-166.

Fisman, R., Iyengar, S. S., Kamenica, E., \& Simonson, I. (2006). Gender differences in mate selection: Evidence from a speed-dating experiment. Quarterly Journal of Economics, 121, 673-697.

Fisman, R., Iyengar, S. S., Kamenica, E., \& Simonson, I. (2008). Racial preferences in dating. Review of Economic Studies, 75, 117-132.

Freud, S. (2006). Psikhopatologiya obydennoi zhizni [The psychopathology of the everyday life]. Moscow: Azbuka-klassika. (Transl. of: Freud, S. (1904). Zur Psychopathologie des Alltagslebens [On the psychopathology of the everyday life]. Berlin: Verlag von S. Karger. (in German)).

Goffman, E. (2000). Predstavlenie sebya drugim v povsednevnoi zhizni [The presentation of self to others in everyday life]. Moscow: Kanon-Press. (Transl. of: Goffman, E. (1959). The presentation of Self in everyday life. Garden City, NY: Anchor Books).

Goffman, E. (2003). Analiz freimov: esse ob organizatsii povsednevnogo opyta [Frame analysis: An essay on the organization of the everyday experience]. Moscow: Institute of Sociology of Russian Academy of Sciences. (Transl. of: Goffman, E. (1974). Frame analysis: An essay on the organization of experience. Boston, MA: Northeastern University Press).

Goffman, E. (2014). Poryadok vzaimodeistviya [The interaction order]. Sotsiologiya Vlasti [Sociology of Power], 1, 163-199. (Transl. of: Goffman, E. (1983). The interaction order. American Sociological Reviere, 48, 1-17).

Gottschalk, L. A, Lolas, F., \& Viney, L. L. (1986). (Eds.). Content analysis of verbal behavior. Significance in clinical medicine and psychiatry. Berlin: Springer-Verlag.

Halliday, M. A. K. (1978). Language as social semiotic: The social interpretation of language and meaning. Baltimore, MD: University Park Press.

Heritage, J. (2008). Conversation analysis as social theory. In B. Turner (Ed.), The new Blackwell companion to social theory (pp. 300-320). Oxford, UK: Blackwell. 
Hindmarsh, J., \& Llewellyn, N. (2010). Finding organisation in detail: methodological orientations. In N. Llewellyn \& J. Hindmarsh (Eds.), Organization, interaction and practice. Studies in ethnomethodology and conversation analysis (pp. 24-46). Cambridge: Cambridge University Press.

Hymes, D. H. (1975). Etnografiya rechi [The ethnography of speech]. In N. S. Chemodanov (Ed.), Novoe v lingvistike [New in linguistics] (Iss. 7, pp. 42-95). Moscow: Progress. (Transl. of: Hymes, D. (1962). The ethnography of speaking. In T. Gladwin \& W. C. Sturtevant (Eds.), Anthropology and human behavior (pp. 13-53). Washington, DC: Anthropology Society of Washington).

Jefferson, G. (1979). A technique for inviting laughter and its subsequent acceptance/declination. In G. Psathas (Ed.), Everyday language: Studies in ethnometodology. New York: Irvington.

Kurzban, R., \& Weeden, J. (2005). HurryDate: Mate preferences in action. Evolution and Human Behavior, 26, 227-244.

Kurzban, R., \& Weeden, J. (2007). Do advertised preferences predict the behavior of speed daters? Personal Relationships, 14, 623-632.

Labov, W. (1975). Issledovanie yazyka v ego sotsial'nom kontekste [The study of the language in its social context]. In N. S. Chemodanov (Ed.), Novoe v lingzistike [New in linguistics] (Iss. 7, pp. 96181). Moscow: Progress.

Luria, A. R. (2002). Priroda chelovecheskikh konfliktov: ob»ektivnoe izuchenie dezorganizatsii povedeniya cheloveka [The nature of the human conflicts: The objective study of disarrangement of human behavior]. Moscow: Kogito-Tsentr.

Ostin, J. L. (1986). Slovo kak deystvie [The word as a deed]. In B. Y. Gorodetskiy (Ed.), Novoe v zarubejnoi lingvistike [New in the foreign linguistics] (Iss. 17, pp. 22-129). Moscow: Progress.

Peräkylä, A., Antaki, C., Vehviläinen, S., \& Leudar, I. (2008). (Eds.). Conversation analysis and psychotherapy. Cambridge: Cambridge University Press.

Potter, J., \& Hepburn, A. (2010). A kind of governance: rules, time and psychology in organizations. In N. Llewellyn \& J. Hindmarsh (Eds.), Organisation, interaction and practice. Studies in ethnomethodology and conversation analysis (pp. 49-73). Cambridge: Cambridge University Press.

Psathas, G. (1995). Conversation analysis: the study of Talk-in-Interaction. Thousand Oaks, CA: Sage.

Rents, T. G. (2011). Romanticheskoe obshchenie v kommunikativno-semioticheskom aspekte [Romantic interaction in communicative-semiotic aspect] (Extended abstract of doctoral dissertation, Volgograd State Pedagogical University, Volgograd, Russian Federation).

Sacks, H. (1984). On doing "being ordinary". In M. Atkinson \& J. Heritage (Eds.), Structures of social action: Studies in conversation analysis (pp. 413-429). Cambridge: Cambridge University Press.

Sacks, H., Schegloff, E. A., \& Jefferson, G. (2015). A simplest systematics for the organization of turntaking for conversation. Russian Sociological Review, 14(1), 142-202. (in Russian) (Transl. of: Sacks, H., Schegloff, E. A., \& Jefferson, G. A (1974). Simplest systematics for the organization of turn-taking for conversation. Language, 50(4), 696-735).

Sinclair, J., \& Coulthard, R. (1975). Towards an analysis of discourse. Oxford: Oxford University Press. Smith, J. A. (Ed.). (2003). Qualitative psychology: A practical guide to research methods. London: Sage.

Tracy, K., \& Robles, J. S. (2015). Povsednevnyi razgovor. Stroenie i otrazhenie identichnosti [Everyday talk: building and reflecting identities]. Kharkiv: Gumanitarnyi Tsentr. (Transl. of: Tracy, K., \& Robles, J. S. (2013). Everyday talk: Building and reflecting identities (2nd ed.). New York/London: The Guilford Press).

Turchik, A. V. (2010). Konversatsionnyi analiz rechevogo vzaimodeistviya v situatsii issledovatel'skogo interv'yu [Conversation analysis of the speech interaction in the situation of the research interview] (Ph.D. dissertation, Peoples' Friendship University of Russia, Moscow). 
Ulanovsky, A. M. (2012). Fenomenologicheskaya psikhologiya: kachestvennye issledovaniya i rabota s perezhivaniem [Phenomenological psychology: Qualitative studies and work with feelings]. Moscow: Smysl.

Zimich, E. V. (2010). Structural semantic and pragmatic peculiarities of the organization of the courting communicative situation. V.N. Karazin Kharkiv National University Bulletin. Series: Philology. Methodology of Teaching Foreign Languages, 930(64), 104-109. (in Russian)

Alexey M. Ulanovsky - associate professor, Faculty of Social Sciences, National Research University Higher School of Economics, Ph.D.

Research area: conversation analysis, group communication, leadership, organizational consulting.

E-mail: a.m.ulanovsky@gmail.com

Ludmila A. Erokhina - psychologist, philologist, postgraduate student, Russian Language Institute of Russian Academy of Sciences.

Research area: psycholinguistics, linguistic analysis of texts, conversation analysis.

E-mail: erokhina_ludmila@inbox.ru

Mikael D. Jan - psychologist, founder of the project ManyChat.

Research area: psychology of communication, information technology, business communication, conversational commerce, chat robots.

E-mail: mike@manychat.com 